\title{
IN DE KEUKEN EN UIT DE KEUKEN. (*)
}

\section{(Ingezonden.)}

\section{AUGURKJES INMAKEN EN SNIJBOONEN KOKEN.}

Wij zijn thans juist in het midden van den tijd waarop de augurkjes worden ingelegd en de versche snijboonen aan de markt zijn. Het is daarom het goede tijdstip om de lezeressen van de Economist opmerkzaam te maken op een misbruik, dat bijna allerwege wordt aangetroffen, dat de nadeeligste gevolgen kan na zich slepen. Wij bedoelen "de kopervergiftiging."

De azijn voor het inmaken van augurkjes bestemd moet, volgens verschillende voorschriften, zoo lang in een koperen ketel worden gekookt, tot hij groen van kleur is. Wat geschiedt hier? De azijn lost een gedeelte koper-oxyde op, en vormt daarmede azijnzuur-koper-oxyde, welk metaalzout de eigenschap bezit, aan de augurkjes eene schoone groene kleur te geven.

Wat zoudt gij zeggen, lezeres! indien ik $\mathfrak{n}$ aanraadde, in een verfwinkel $b$. v. een ons spaanschgroen te halen, hetwelk gij weet dat tot de zware vergiften behoort, en dit in den azijn te smelten? Weet gij wel, dat, wanneer de azijn in een koperen ketel wordt gekookt, er eveneens SPAANSCHGROEN wordt gevormd?

Gaarne veronderstellen wij, dat zulk koken van den azijn slechts eene gewoonte is die gij voor onschuldig houdt, doch raden $u$ ten sterkste aan die te laten varen, wijl de alzoo bereidde augurkjes een bepaald vergift bevatten, hetwelk hoogst schadelijk is voor de gezondheid.

Het koken van snijboonen in koperen ketels is even gevaarlijk: een gedeelte van het koper verbindt zich met de snijboonen, en maakt deze tot een even schadelijk voedsel als boven van de augurkjes is gezegd.

Laat ons liever een weinig minder groen gekleurde spijze op tafel brengen, dan aan huisgenooten en vrienden een vergift voorzetten, dat, hoewel het niet dadelijk doodelijk kan genoemd worden, toch zeer schadelijk voor de gezondheid is.

Houden wij dus het spaanschgroen uit de keuken.

's Gravenhage, Augustus 1856.

N.

(*) Onder dezen titel zullen wij van tijd tot tijd eenige stukjes plaatsen, op het huishouden betrekking hebbende. 